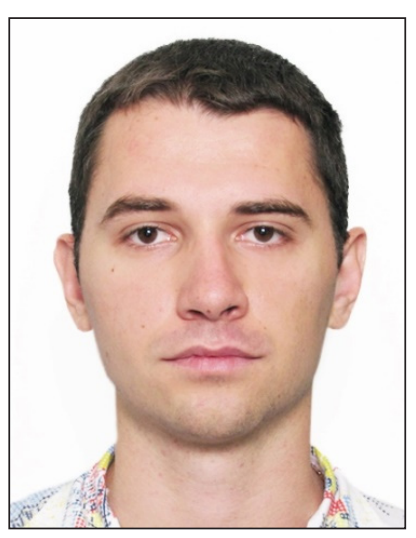

Любченко Ярослав Павлович, молодший науковий співробітник, Науково-дослідний інститут державного будівничтва та місцевого самоврядування, Національна академія правових наук України, Україна, м. Харків e-mail:liubchenko.iaroslav@gmail.com

\title{
YAK 340.1
}

\section{УАОСКОНААЕННЯ НАЦІОНААЬНОГО ЗАКОНОААВСТВА У СФЕРІ ААЬТЕРНАТИВНИХ СПОСОБІВ ВИРІШЕННЯ ПРАВОВИХ СПОРІВ}

У статті розглядаються недоліки чинного законодавства та міжнародний досвід у сфері альтернативних способів вирішення правових спорів, висвітлюються пропозиції по удосконаленню чинного законодавства для підвищення інвестиційної привабливості України.

Ключові слова: арбітраж; медіація; законопроект; законодавство; альтернативні способи вирішення правових спорів; судова влада; виконання рішень суду.

Любченко Я. П., младший научный сотрудник, Научно-исследовательский институт государственного строительства и местного самоуправления, Национальная академия правовых наук Украины, Украина, г. Харьков.

e-mail: liubchenko.iaroslav@gmail.com

Усовершенствование национального законодательства в сфере альтернативных способов решения правовых споров

В статье рассматриваются недостатки действующего законодательства и международный опьт в сфере альтернативных способов разрешения правовых споров, освещаюттся предложения по усовершенствованию действующего законодательства для повышения инвестиционной привлекательности Украины.

Ключевые слова: арбитраж; медиация; законопроект; законодательство; альтернативные способы решения правовых споров; судебная власть; исполнение решений суда.

Постановка проблеми. Чинне законодавство нині належним чином не регулює застосування альтернативних способів вирішення правових спорів. Тож є необхідність внесення змін у чинне законодавство для забезпечення відповідності його міжнародним стандартам, зобов’язанням України у зв’язку з підписанням Угоди про асоціацію з СС та задля ефективного використання альтернативних способів вирішення правових спорів (далі ADR) сторонами відносин. 
Ажтуальність теми. Невирішеність багатьох теоретичних питань альтернативних форм та способів вирішення правових спорів і конфліктів, а також практична необхідність у розвитку цього механізму зумовлюють необхідність активізації грунтовних досліджень у цій сфері.

Аналіз останніх досліджень і публікащій. Проблеми альтернативних способів вирішення спорів у своїх працях розглядали Н. Л. Бондаренко-Зелінська, Ю. Д. Притика, О. М. Спектр, В. Ф. Яковлева та ін.

Метою статmi є аналіз пропозицій Конституційної комісії у сфері правосуддя, а також аналіз законопроектів, пов'язаних з альтернативними способами вирішення правових спорів, дослідження проблем правового регулювання відносин у вказаній сфері, що сприятиме оптимізації процедур та удосконаленню законодавства в цілому.

Виклад основного матеріалу. Здійснення економічних, політичних, державно-правових та інших реформ у суспільстві зумовлює значне посилення соціально-правової напруженості, виникнення великої кількості конфліктів у правовій сфері. Традиційно захист порушених прав і охоронюваних законом інтересів здійснюється судами, які організовуються і фінансуються державою. Але судочинство при багатьох очевидних перевагах має і низку недоліків: велика завантаженість судів, тривалість і складність судочинства, значні судові витрати, належним чином не відпрацьований механізм реалізації принципу змагальності і рівності сторін у процесі, критерії справедливості вирішення спору часто не збігаються з уявленнями про справедливість людей, що не мають юридичної підготовки, тому дуже часто рішення суду викликають негативну реакцію у сторін, в результаті конфлікт припиняється примусовим рішенням суду, але не розв'язується, у зв'язку з чим судові рішення не виконуються.

Монопольне становище судової гілки влади та закріплена у ст. 124 Конституції України норма, згідно з якою юрисдикція судів поширюється на всі правовідносини, що виникають у державі, часом призводить до абсурдних позовів, зловживання правом на звернення до суду, надмірного завантаження судової системи i, як результат, до судової тяганини, яка може тривати роками, а справа по декілька разів проходити всі інстанції.

Упродовж останніх років річний показник виконання судових рішень коливається близько 30 \%. Так, у 2006 р. підлягало виконанню органами Державної виконавчої служби 7137858 рішень, з них фактично виконано 2406624 (33,7 \%); у 2007 р. з 7316781 рішення виконано 2391201 (32,7 \%); у 2008 р. з 7982785 рішень виконано 2760682 (34,6 \%); у 2009 р. з 8413201 рішення виконано 2671387 (31,8 \%); у 2010 р. з 9378377 рішень виконано 2982808 (31,8 \%); у 2011 р. з 9573395 рішень виконано 3193255 (33,4 \%). Аналізуючи статистичні показники, учасники парламентських слухань 22.05.2013 р. на тему «Про стан виконання судових рішень в Україні» звернули увагу на певну диспропорцію [1]. Так, колишній Голова Вищого господарського суду України В. І. Татьков, аналізуючи статистичну інформацію, наведену у звітах Державної виконавчої служби України про роботу її органів у 2011-2012 рр., стверджував, що кількість завершених виконавчих проваджень становить при- 
близно дві третини з тих, що підлягали примусовому виконанню. Проте якщо аналізувати розмір сум, стягнутих органами Державної виконавчої служби за виконавчими документами, бачимо цілком протилежну ситуацію: менше третини вимог кредиторів задоволено шляхом примусового виконання судових рішень органами Державної виконавчої служби.

У 2015 р. Президентом України була створена Конституційна комісія, яка займається розробкою пропозицій щодо змін до Конституції України для ï відповідності реаліям сьогодення. Розділ 8 Конституції України «Правосуддя» Конституційна комісія запропонувала доповнити наступною статтею: «Законом може бути передбачений обов'язковий досудовий порядок врегулювання спору» [2].

Таким чином, Конституційна комісія пропонує передбачити правове запровадження альтернативних способів вирішення спорів для того, щоб зменшити навантаження на судову систему, адже певні спори завершуються на стадії переговорів або шляхом укладення мирової угоди. Ця норма може свідчити про важливість для держави врегулювання спорів незалежно від того, якими способами вони будуть розв'язані. Застосування ADR ніколи не зможе замінити собою судову систему, адже, наприклад, міжнародний арбітраж базується на можливості винесення рішення державного суду у випадку невиконання стороною добровільно певного рішення арбітражного суду (мова йде про визнання та виконання рішення іноземного суду).

Міжнародним комерційним арбітражним судом при Торгово-промисловій палаті України у 2014 р. було розглянуто 696 справ [3]. Навіть якщо врахувати, що деякі з них були оскаржені до національних судів, то всі ці спори вирішились за допомогою альтернативного способу вирішення спорів (міжнародного арбітражу). Таким чином, держава лише виграє від функціонування такої системи.

Існують проблеми, з якими стикається міжнародний арбітраж: найбільш важливі з них - це механізми реалізації тимчасових забезпечувальних заходів у рамках арбітражного процесу, а також складнощі з виконанням рішень арбітражу.

Для вирішення вищенаведених проблем необхідно вносити зміни в чинне законодавство шляхом прийняття законопроектів. Проаналізувавши законопроекти, які вносились народними депутатами 7 та 8 скликання, можна дійти висновку, що лише один з них стосувався пропозицій щодо змін до нормативно-правових актів у такій важливій сфері, як міжнародний арбітраж - Проект Закону про внесення змін до деяких законодавчих актів України (щодо вжиття заходів забезпечення позову у підтримку міжнародного арбітражу) (законопроект № 3366 від 07.10.2013 р.) [4].

На наш погляд, цей законопроект є надзвичайно важливим, оскільки пропонує актуальні зміни, які мали б бути прийняті ще два роки тому. Закон України «Про міжнародний комерційний арбітраж» грунтується на положеннях Модельного закону ЮНСІТРАЛ про міжнародний комерційний арбітраж, 
який є основою для законодавства про арбітраж у більш ніж 30 країнах світу. Закон України «Про міжнародний комерційний арбітраж» (ст. 9), як і Модельний закон ЮНСІТРАЛ, надає право сторонам арбітражного розгляду звернутися до державного суду з проханням про вжиття забезпечувальних заходів до або під час арбітражного розгляду з метою забезпечення виконання арбітражного рішення в майбутньому. Право сторін на звернення до суду з проханням про вжиття забезпечувальних заходів застосовується до арбітражного розгляду, який відбувається як на території України, так і за кордоном.

Процесуальне законодавство України не містить механізму реалізації цього права. Арбітри у рамках арбітражного розгляду можуть самостійно виносити рішення щодо застосування забезпечувальних заходів, але на практиці дуже часто виникають складнощі з примусовим виконанням цих заходів. Законодавство багатьох країн надає можливість державним судам приймати рішення про застосування засобів забезпечення в підтримку міжнародного арбітражу. Відсутність ефективного механізму реалізації аналогічних заходів у нашому законодавстві негативно впливає на ставлення іноземних інвесторів до України.

Прийняття такого законопроекту сприятиме приведенню процесуального законодавства України у відповідність із міжнародною законодавчою практикою щодо повноважень державних судів виносити рішення про забезпечення прав та інтересів осіб, які беруть участь в арбітражному розгляді та гарантувати ефективне виконання арбітражних рішень в Україні, що, у свою чергу, буде сприяти покращенню інвестиційної привабливості України.

Що стосується виконання рішень арбітражних судів в України, то тут також існує неоднозначна практика державних судів, які інколи скасовують цілком правові рішення у зв'язку з тим, що вони суперечать публічному порядку України, хоча цей термін не визначено у чинному законодавстві. Пункт 18 постанови Пленуму Верховного Суду України «Про судову практику розгляду цивільних справ про визнання правочинів недійсними» від 06.11.2009 р. № 9 [5] визначає перелік правочинів, які є нікчемними у зв'язку з тим, що вони порушують публічний порядок. Правові наслідки таких правочинів визначаються ст. 228 Цивільного кодексу України.

Проте чинне законодавство України не визначає а ні поняття «публічний порядок», а ні його ознак. Разом із тим постановою Пленуму Верховного Суду України «Про судову практику розгляду цивільних справ про визнання правочинів недійсними» від 06.11.2009 р. № 9 встановлено, які правочини належать до таких, що порушують публічний порядок, і ті, що публічного порядку не порушують. Таким чином, цей перелік є вичерпним.

Наведений приклад характеризує постанову Пленуму як таку, що за своїм змістом створює норму права, яку в подальшому використовують на практиці, тобто фактично здійснює нормотворчу функцію, хоча постанови будьяких судів не є джерелом права відповідно до юридичної доктрини України. Тому існує нагальна необхідність врегулювати суспільні відносини у цій сфері нормативно-правовими актами. 
Серед учених досі тривають дискусії, щодо необхідності Закону «Про медіацію» в України. Протягом останніх п'яти років у Верховній Раді України було зареєстровано три законопроекти, але жоден з них не став законом.

Існують різні підходи щодо вирішення цього питання. Противники прийняття закону відзначають, що він обмежуватиме певними рамками діяльність медіаторів та сферу їх діяльності, адже стосовно поняття медіації також точаться дискусії. Інші стверджують, що медіація взагалі не є чимось новим, а звичайною буденною роботою адвоката, який спілкується з клієнтом, тобто представляючи інтереси клієнта адвокат здійснює медіацію.

21.03.2014 р. Україною було підписано політичну частину Угоди про асоціацію між Україною та $Є С$, економічна частина Угоди була підписана 27.06.2014 р. Необхідністю для дослідження альтернативних способів вирішення спорів стала орієнтація на інтеграцію в європейське співтовариство, у зв'язку з чим одним з пріоритетних напрямів стратегічного розвитку України є забезпечення відповідності національної правової системи стандартам європейської спільноти загалом та створення справді ефективного механізму захисту прав та свобод людини і громадянина зокрема. 3 огляду на це постало питання про суттєве реформування національної системи захисту цивільних прав та інтересів, яка наразі формується переважно за рахунок юрисдикційних органів.

Наявність в Угоді про асоціацію низки положень щодо альтернативного вирішення спорів також свідчить про визнання Євросоюзом певних досягнень України у даній сфері та у розвитку ринкової економіки і демократичних інститутів у цілому [6].

За відсутності національного законодавства в галузі медіації Україна, ратифікувавши Угоду про асоціацію, вперше на державному рівні визначила механізм посередництва як засіб врегулювання спорів у такій важливій сфері, як відносини з Свросоюзом.

Разом із тим змушені констатувати, що в Україні розвиток альтернативних форм і способів вирішення правових спорів та конфліктів перебуває у зародковому стані. Якщо третейські суди є певною мірою традиційною формою для правової практики, то медіація, примирення та інші способи пошуку компромісу відносно нові для України. Відсутність значного поширення в Україні результативних процедур й усталеної практики альтернативних способів врегулювання та вирішення правових спорів зумовлене специфічними національними особливостями, недостатнім закріпленням на законодавчому рівні приписів щодо можливості їх застосування, (як правило, жодне нововведення в правовій сфері не приживається без прямої вказівки закону), незнанням суті та ефективності даних процедур зацікавленими особами (сторонами конфлікту, представниками органів державної влади, широкої юридичної громадськості), невмінням багатьох практикуючих юристів використовувати потенціал, закладений у названих процедурах.

Для України є важливим розвиток альтернативних способів вирішення правових спорів та юридичної конфліктології. Не тільки через підписання Угоди 
про асоціацію з $\mathrm{CC}$, а також через те, що Україна є активним учасником міжнародних відносин. Наприклад, спори, пов'язані з результатами спортсменів на Олімпійських іграх, інвестиційні міжнародні спори, конфлікти між країнами та ін. Зазвичай для врегулювання конфліктів у міжнародній сфері використовуються альтернативні способи вирішення правових спорів, адже національні суди не викликають довіри і не мають достатнього досвіду для вирішення подібних спорів. Вищенаведене свідчить про потребу пошуку нових шляхів, форм і способів розв'язання конфліктів, необхідність грунтовних теоретичних і практичних знань про позасудові (альтернативні) можливості врегулювання правових спорів та формуванні державної політики у сфері альтернативних способів вирішення правових спорів.

Дослідження зобов'язань України та новел, які запроваджує Угода про Асоціацію, а також стандарти $\mathrm{CC}$ у сфері ADR буде досліджено нами в окремій статті.

Висновки. Висвітлення проблеми альтернативного вирішення правових спорів у вітчизняній науковій літературі має здебільшого узагальнюючий, теоретичний характер. Різноманітні альтернативні форми, процедури, способи існують і застосовуються в іноземних державах поряд з традиційним судочинством. Вони не замінюють судочинства і не позбавляють зацікавлених осіб права на судовий захист. Навпаки, надають їм можливість вибору між державною чи недержавною (приватною) формами вирішення правових конфліктів, дозволяють сторонам самим вирішувати, який вид процедури найкращим чином сприяє вирішенню конкретного правового спору.

Необхідно змінювати національне законодавство для ефективного використання альтернативних способів вирішення правових спорів у зв'язку із євроінтеграційним курсом, обраним Україною. Також слід запроваджувати альтернативні способи вирішення правових спорів у законодавство для відповідності національного законодавства України світовим стандартам.

\section{Список літератури:}

1. Мулявка Д. Г. Підвищення ефективності виконання судових рішень [Електронний ресурс] / Д. Г. Мулявка // Юридичний науковий електроний журнал. - 2014. - Режим доступу : http://www.lsej.org.ua/5_2014/42.pdf.

2. Проект змін до Конституції України в частині правосуддя [Електронний ресурс]. 2015. - Режим доступу : http://constitution.gov.ua/work/item/id/13.

3. Динамика количества дел МКАС 2000-2014 [Електронний ресурс]. - 2015. - Режим доступу : http://arb.ucci.org.ua/icac/ru/report.html.

4. Законопроект «Про внесення змін до деяких законодавчих актів (щодо вжиття заходів забезпечення позову у підтримку міжнародного арбітражу)» [Електронний ресурс]. - 2013. Режим доступу : http://w1.c1.rada.gov.ua/pls/zweb2/webproc4_1?pf3511=48574.

5. Постанова Пленуму Верховного Суду України «Про судову практику розгляду цивільних справ про визнання правочинів недійсними» від 06.11.2009 р. № 9 [Електронний ресурс]. 2009. - Режим доступу : http://zakon5.rada.gov.ua/laws/show/v0009700-09.

6. Угода про асоціацію між Україною та Європейським Союзом [Електронний ресурс]. 2014. - Режим доступу : http://www.kmu.gov.ua/control/uk/publish/article?art_id=248387631. 


\section{Rerences:}

1. Muliavka, D. H. (2014) "Pidvyshchennia Efektyvnosti Vykonannia Sudovykh Rishen.» Yurydychnyi Naukovyi Elektronyi Zhurnal : n. pag. Web. 24 Nov. 2015. <http://www.lsej.org.ua/5_2014/42. pdf $>$

2. Proekt Zmin Do Konstytutsii Ukrainy v Chastyni Pravosuddia. (2015) Constitution Commission. N.p., n.d. Web. 24 Nov. 2015. <http://constitution.gov.ua/work/item/id/13>

3. Dynamyka Kolychestva Del MKAS 2000-2014. Rep. N.p., n.d. Web. 24 Nov. 2015. <http:// arb.ucci.org.ua/icac/ru/report.html>

4. Ukraine. Parliament. Zakonoproekt «Pro Vnesennia Zmin Do Deiakykh Zakonodavchykh Aktiv (shchodo Vzhyttia Zakhodiv Zabezpechennia Pozovu U Pidtrymku Mizhnarodnoho Arbitrazhu)». N.p., n.d. Web. 24 Nov. 2015. <http://w1.c1.rada.gov.ua/pls/zweb2/webproc4_1?pf3511=48574>.

5. Postanova Plenumu Verkhovnoho Sudu Ukrainy «Pro Sudovu Praktyku Rozghliadu Tsyvilnykh Sprav Pro Vyznannia Pravochyniv Nediisnymy» vid 06.11.2009 № 9.» N.p., n.d. Web. 24 Nov. 2015. <http://zakon5.rada.gov.ua/laws/show/v0009700-09>

6. Uhoda Pro Asotsiatsiiu Mizh Ukrainoiu Ta Yevropeiskym Soiuzom.» N.p., n.d. Web. 24 Nov. 2015. <http://www.kmu.gov.ua/control/uk/publish/article?art_id=248387631>.

Liubchenko I., research fellow National Academy of Legal Sciences of Ukraine, Ukraine, Kharkiv. e-mail: liubchenko.iaroslav@gmail.com.

\section{Improvement of national legislation in alternative resolution of legal disputes area}

Current legislation does not adequately regulate using of alternative dispute resolution. The article emphasizes the need for amending existing legislation to ensure its compliance with international standards, its obligations in connection with the signing of the Association Agreement and ensure efficient use of alternative dispute resolution (hereinafter - ADR) party relations.

Problems of alternative dispute resolution were viewed in their works viewed N. Bondarenko-Zelinska, Y. Pritika, O. Spectr, A. Shypilova, V. Yakovleva and others.

The article goal is to analyze the proposals of the Constitutional Commission in the field of justice, as well as analysis of bills related to ADR, research of problems of legal regulation, which will help optimize procedures and improve the law in general.

Realization of economic, political, governmental, legal and other reforms in society lead to a significant strengthening of social and legal tensions, the emergence of a large number of conflicts in the legal field. Traditionally, parties use courts that are organized and funded by the state in order to protect rights and legal interests. However, justice for many obvious advantages has several disadvantages: a large workload of courts, length and complexity of the proceedings, considerable legal costs not properly worked out mechanism of the principle of competition and equality.

Problems of alternative dispute resolution in domestic legal literature are mostly synthesis and theoretical. Various alternative forms, procedures, and methods are used by foreign countries, along with the traditional proceedings. They do not replace justice and do not deprive the persons right for judicial protection. Instead, give them a choice between public or non-governmental (private) forms of resolving legal disputes, allowing parties to decide which type of procedures will help to resolve specific legal dispute.

The paper analyze limitations of current legislation and international experience in alternative dispute resolution area, author highlights proposals for improvement of legislation to improve investment attractiveness of Ukraine.

Key words: arbitration; mediation; bill, legislation; alternative dispute resolution; court branch of law; execution of court decision.

Надійшла до редколегії 15.11.2015 p. 